JURNAL KETAHANAN NASIONAL

Vol. 25, No. 1, April 2019, Hal 92-106

DOI:http://dx.doi.org/ 10.22146/jkn.39544

ISSN:0853-9340 (Print), ISSN:2527-9688 (Online)

Online sejak 28 Desember 2015 di :http://jurnal.ugm.ac.id/JKN

VOLUME 25

No. 1, April 2019

Halaman 92-106

\title{
Tipologi Pola Konsumsi Pangan Untuk Menjaga Ketahanan Pangan Masyarakat Sekitar Kawasan Hutan Lindung Mutis Timau KPH Kabupaten Timor Tengah Selatan
}

\author{
Fransiskus Xaverius Dako \\ Program Pascasarjana Fakultas Kehutanan Universitas Gadjah Mada dan Politeknik Pertanian \\ Negeri Kupang \\ email: dakoxaverjurnal@gmail.com (Correspondent Author)
}

Ris Hadi Purwanto

Fakultas Kehutanan Universitas Gadjah Mada. email: risuhadi@yahoo.com

Lies Rahayu W. Faida

Fakultas Kehutanan Universitas Gadjah Mada email: 1rahayu@ugm.ac.id

Sumardi

Fakultas Kehutanan Universitas Gadjah Mada email: sumardibdh@yahoo.com

\begin{abstract}
This study aimed to determined the consumption of various types of foodstuffs by the people in and around the Mutis Timau protected forest area, South Central Timor District Forest Management Unit.

The method used was a survey method with a qualitative and quantitative approach with a sample of 353 farmer households distributed proportionally to each village which included Nunbena, Noebesi, Leloboko, Tunua, Ajaobaki, Nuapin, Nenas, Kuanoel, and Fatumnasi. The research was conducted through several stages which included the preparation stage, data collection and analysis phase. Methods of data collection in this study were conducted using structured questionnaires, in-depth interviews, field observations, and literature studies. The data obtained was processed by tabulating data and then analyzed qualitatively and quantitatively by a descriptive method.

The results showed that consumption of various types of food per family per day varied in each village with an average consumption of rice $0.86 \mathrm{~kg}$, corn $0.83 \mathrm{~kg}$, cassava $0.25 \mathrm{~kg}$, sweet potatoes $0.28 \mathrm{~kg}$, green beans $0.10 \mathrm{~kg}$ and tourist nuts $0.09 \mathrm{~kg}$. While the average consumption per capita per day for rice was $0.18 \mathrm{~kg}$, corn was $0.17 \mathrm{~kg}$, cassava was $0.05 \mathrm{~kg}$, sweet potatoes were $0.06 \mathrm{~kg}$, green beans were $0.02 \mathrm{~kg}$ and nuts were $0.01 \mathrm{~kg}$. The number of households that consumed the type of food that was combined every time they cooked includes corn rice (BJ) $12.46 \%$, sweet potato rice (BJU) $60.05 \%$, corn sweet potato rice (BJUK) $24.92 \%$, corn bean rice (BJK) $1.41 \%$ and sweet potato $(B U) 1.13 \%$. This combination of eating patterns showed that there were efforts made by households in the society to maintained family food resilience, and widely to maintained society food resilience
\end{abstract}

Keywords: Consumption of Food, Society Food Resilience. 
Fransiskus Xaverius Dako, Ris Hadi Purwanto, Lies Rahayu W.Faida, Sumardi -- Tipologi Pola Konsumsi Pangan Untuk Menjaga Ketahanan Pangan Masyarakat Sekitar Kawasan Hutan Lindung Mutis Timau KPH

Kabupaten Timor Tengah Selatan

\begin{abstract}
ABSTRAK
Penelitian ini bertujuan untuk mengetahui konsumsi berbagai jenis bahan makanan oleh masyarakat yang berada di dalam dan sekitar kawasan hutan lindung Mutis Timau, Kesatuan Pengelolaan Hutan Kabupaten Timor Tengah Selatan.

Metode yang digunakan adalah metode survey dengan pendekatan kualitatif dan kuantitatif dengan sampel 353 KK petani yang terdistribusi secara proporsional pada setiap desa yang meliputi Nunbena, Noebesi, Leloboko, Tunua, Ajaobaki, Nuapin, Nenas, Kuanoel dan Fatumnasi. Penelitian dilakukan melalui beberapa tahapan yang meliputi tahap persiapan, tahap pengumpulan dan analisis data. Metode pengumpulan data dalam penelitian ini dilakukan dengan menggunakan kuesioner terstruktur, wawancara mendalam, observasi lapangan dan studi literatur. Data yang diperoleh diolah dengan melakukan tabulasi data dan selanjutnya dianalisis secara kualitatif dan kuantitatif dengan metode deskriptif.

Hasil penelitian menunjukkan bahwa konsumsi berbagai jenis bahan makanan setiap keluarga per hari bervariasi pada setiap desa dengan rata-rata konsumsi beras $0,86 \mathrm{~kg}$, jagung 0,83 kg, ubi kayu 0,25 kg, ubi jalar $0,28 \mathrm{~kg}$, kacang hijau 0,10 kg, dan kacang turis $0,09 \mathrm{~kg}$. Sedangkan konsumsi rata-rata per kapita per hari untuk beras $0,18 \mathrm{~kg}$, jagung $0,17 \mathrm{~kg}$, ubi kayu $0,052 \mathrm{~kg}$, ubi jalar 0,058 kg, kacang hijau 0,02 kg, dan kacang turis $0,01 \mathrm{~kg}$. Jumlah rumah tangga yang mengkonsumsi jenis bahan makanan yang dikombinasikan setiap kali masak meliputi beras jagung (BJ) $12,46 \%$, beras jagung ubi (BJU) 60,05\%, beras jagung ubi kacang (BJUK) $24,92 \%$, beras jagung kacang (BJK) 1,41\% dan beras ubi (BU) 1,13\%. Kombinasi pola makan ini menunjukkan bahwa ada upaya yang dilakukan oleh rumah tangga di masyarakat untuk menjaga ketahanan pangan keluarga, dan secara meluas untuk menjaga ketahanan pangan masyarakat.
\end{abstract}

\title{
Kata Kunci : Konsumsi Pangan, Ketahanan Pangan Masyarakat.
}

\section{PENGANTAR}

Indonesia merupakan salah satu negara agraris yang mempunyai lahan pertanian luas dan subur, terletak di garis khatulistiwa dengan penduduk yang beranekaragam serta sebagian besar bermatapencaharian sebagai petani (Wibowo, 2018). Hal ini didukung dengan lahan pertanian yang subur baik lahan basah (sawah) maupun lahan kering (kebun/ladang) dan terbentang luas dari ujung Barat (Sabang) sampai ujung Timur (Merauke), ujung Utara (Miangas) dan ujung Selatan (Rote). Janti, dkk. (2016) menyatakan bahwa lahan pertanian memiliki peran dan fungsi strategis sebagai sumber daya pokok dalam usaha pertanian berbasis lahan. Lahan merupakan sumber daya alam yang bersifat langka karena jumlahnya tidak bertambah, tetapi kebutuhan terhadap lahan selalu meningkat. Sementara lahan hutan sebenarnya merujuk pada pengertian hutan itu sendiri (UU Nomor 41 Tahun 1999) yang menyatakan bahwa hutan merupakan suatu kesatuan ekosistem berupa hamparan lahan berisi sumber daya alam hayati yang didominasi pepohonan dalam persekutuan alam lingkungannya, yang satu dengan lainnya tidak dapat dipisahkan. Dengan demikian lahan hutan dapat diartikan sebagai lahan yang berisi sumber daya alam hayati. Dako, dkk. (2018) menjelaskan bahwa hutan menyediakan berbagai potensi sumber daya berupa hasil hutan kayu dan bukan kayu yang dapat dimanfaatkan oleh manusia secara optimal dan lestari.

Awang (2006) menjelaskan bahwa masyarakat mempunyai hubungan yang erat pada sumber daya hutan dan kehidupannya sangat bergantung dari potensi yang ada di hutan terutama dalam pemenuhan bahan pangan langsung dari dalam hutan seperti berburu hewan, bahan pangan, buahbuahan, dan bahan konstruksi bangunan. Dwiprabowo, dkk. (2011) menjelaskan bahwa hutan merupakan sumber daya potensial, sumber pangan, obat-obatan, energi, sandang, lingkungan, dan sekaligus sebagai tempat 
tinggal masyarakat. Dalam sistem pengelolaan hutan, masyarakat mengelola lahannya dengan pola perladangan untuk ditanami pohon serta pada lantai hutan ditanami dengan tanaman pangan, palawija dan obat-obatan.

Mayrowani dan Ashari (2011) menjelaskan bahwa pemanfaatan sumber daya hutan dalam pemenuhan kebutuhan pangan secara tidak langsung hutan sebagai penyangga sistem kehidupan (life supporting sistem) termasuk sistem pertanian pangan dan secara langsung hutan sebagai penyedia pangan (forest for food production). Jenis pangan yang dikembangkan di lahan hutan berupa padi, jagung, kacang-kacangan, umbi-umbian, buah-buahan, tanaman obat serta jenis hewani dalam bentuk daging dari satwa hutan. Semua komoditas yang ditanam oleh masyarakat merupakan suatu upaya dan strategi pemenuhan kebutuhan hidup untuk menjaga ketahanan pangan dalam keluarganya. Tanaman yang ditanam oleh masyarakat dan ketersediaan bahan pangan di suatu daerah sangat berpengaruh pada kebiasaan makan setiap hari dan kebiasaan makan setiap hari akan sangat menentukan pola konsumsi makan masyarakat. Paudel (2018) mengatakan bahwa penggunaan hutan yang dikelola oleh masyarakat tampaknya lebih partisipatif dan ditemukan konsumsi makanan mereka yang memadai. Hutan yang dikelola oleh masyarakat dapat menjadi sarana yang efektif untuk mengatasi kerawanan pangan di negara berkembang.

Pangan merupakan kebutuhan manusia yang paling azasi, sehingga ketersediaan pangan bagi masyarakat harus selalu terjamin untuk mencapai kualitas hidup yang maju, mandiri, tentram, serta sejahtera lahir dan batin (Sa'diyah, 2015). Purwaningsih (2008) menyatakan bahwa kebutuhan pangan senantiasa meningkat seiring dengan peningkatan jumlah penduduk. Dari sisi pemenuhannya, tidak semua kebutuhan pangan dapat dipenuhi karena kapasitas produksi dan distribusi pangan semakin terbatas. Margareta dan Purwidiani (2014) menjelaskan, ketersediaan bahan pangan di suatu daerah berpengaruh pada pola konsumsi makan masyarakat setempat.

Kebiasaan makan orang-orang memiliki implikasi utama untuk penggunaan sumber daya, mengingat meningkatnya persaingan akan tanah, air, energi, dan input lain di masa depan (Garnett, dkk., 2013; Tilman, dkk., 2001). Banyak upaya telah menargetkan sisi produksi, namun mengelola permintaan konsumsi makanan yaitu kebiasaan orang makan dapat memberikan manfaat tambahan yang penting dari perspektif lahan, air, dan energi (Blas, dkk.,2018). Konsumsi makanan merupakan penggerak utama defisit ekologis kawasan, dimana permintaan akan sumber daya yang dapat diperbarui dan layanan ekosistem melebihi kapasitas ekosistemnya (Galli, dkk.,2017). Notarnicola, dkk. (2017), menjelaskan bahwa konsumsi makanan adalah salah satu penggerak utama dari dampak lingkungan. Di satu sisi, ada kebutuhan untuk memenuhi kebutuhan manusia yang mendasar akan nutrisi, dan di sisi lain menimbulkan ancaman kritis terhadap lingkungan hidup. Konsumsi pangan masyarakat yang berada di sekitar kawaan hutan lindung Mutis Timau sampai saat ini belum dikaji secara komprehensif dan telah menjadi hal yang umum bahwa konsumsi pangan masyarakat sangat tergantung pada letak geografis dan ketersediaan bahan pangan. Hal ini mendorong penulis untuk mengkaji pola konsumsi masyarakat sesuai dengan komoditi pangan yang tersedia dan dikonsumsi oleh masyarakat. 
Fransiskus Xaverius Dako, Ris Hadi Purwanto, Lies Rahayu W.Faida, Sumardi -- Tipologi Pola Konsumsi Pangan Untuk Menjaga Ketahanan Pangan Masyarakat Sekitar Kawasan Hutan Lindung Mutis Timau KPH Kabupaten Timor Tengah Selatan

Penelitian dilakukan selama 5 bulan yang berlangsung dari September 2017 sampai Januari 2018, di 9 (sembilan) desa yang berada di sekitar kawasan hutan lindung Mutis Timau, Kesatuan Pengelolaan Hutan Wilayah (KPH) Kabupaten Timor Tengah Selatan, Provinsi Nusa Tenggara Timur meliputi Desa Nunbena, Noebesi, Leloboko, Tunua, Ajaobaki, Nuapin, Nenas, Kuanoel dan Fatumnasi. Perolehan data tersebut melibatkan semua keluarga (KK) pada setiap desa dan pengambilan sampel mengacu pada formula Sevila, dkk. (1993) dengan batas kesalahan yang ditoleransi $5 \%$ sehingga sampel dalam penelitian ini adalah $353 \mathrm{KK}$ petani yang terbagi secara proporsional pada setiap desa sesuai dengan jumlah KK yang ada. Teknik pengambilan sampel menggunakan sampel acak sederhana (simple random sampling). Alat dan bahan yang digunakan dalam penelitian ini meliputi: GPS, kamera, alat tulis menulis, kuesioner, dan jenis dokumen lainnya yang berkaitan dengan pola konsumsi pangan. Penelitian ini menggunakan metode survey dengan pendekatan kualitatif dan kuantitatif untuk melihat pola konsumsi pangan di 9 desa yang berada disekitar hutan lindung Mutis Timau KPH Kabupaten Timor Tengah Selatan Provinsi Nusa Tenggara Timur. Survei konsumsi pangan rumah tangga dilakukan dengan kuesioner terstruktur, wawancara mendalam, observasi lapangan, dan studi literatur.

Penelitian dilakukan dengan beberapa tahapan yang meliputi tahap persiapan, tahap pengumpulan dan analisis data. Data yang diambil adalah data konsumsi pangan dan dalam penilitian ini dibatasi pada jenis bahan makanan yang sering dikonsumsi oleh masyarakat setempat seperti beras, jagung, ubi kayu, ubi jalar, kacang hijau, dan kacang turis.
Caranya adalah dengan mencatat sekaligus menghitung jumlah beras, jagung, ubi kayu, ubi jalar, kacang hijau dan kacang turis yang digunakan oleh setiap keluarga pada setiap kali masak pada setiap hari. Data yang diperoleh tersebut diolah dengan melakukan tabulasi data dan selanjutnya dianalisis secara kualitatif dan kuantitatif dengan metode deskriptif.

\section{PEMBAHASAN}

\section{Konsumsi Berbagai Jenis Pangan Oleh Masyarakat}

Konsumsi pangan pada suatu komunitas yang terdapat di suatu daerah sangat tergantung dengan ketersediaan makanan yang diperoleh masyarakat, baik yang berasal dari lahan milik maupun yang dibeli dari pasar. Ketersediaan makanan merupakan suatu kondisi dalam penyediaan makanan yang mencakup makanan dan minuman yang berasal dari tanaman, ternak atau ikan bagi rumah tangga dalam kurun waktu tertentu. Ketersediaan makanan dalam rumah tangga dipengaruhi oleh tingkat pendapatan (Baliwati dan Roosita, 2002). Seperti diketahui secara umum masyarakat yang berada disekitar kawasan hutan baik hutan produksi, hutan konservasi maupun hutan lindung rata-rata berada di bawah garis kemiskinan. Kemiskinan suatu masyarakat dapat dilihat dari pendapatan yang diperoleh maupun konsumsi pangan yang terdapat di masyarakat. Pangan merupakan kebutuhan pokok masyarakat dan pangan yang tidak memenuhi persyaratan kesehatan yang baik walaupun mengenyangkan, harus dianggap sebagai belum cukup (Simon, 2004). Menurut Badan Pusat Statistik Indonesia, untuk konsumsi makanan referensi waktu yang digunakan adalah seminggu terakhir. Kebutuhan pangan pada penelitian ini dibatasi pada konsumsi beras, jagung, ubi kayu, ubi 
Tabel 1

Konsumsi Berbagai Jenis Pangan Oleh Masyarakat Per Keluarga

\begin{tabular}{|c|c|c|c|c|c|c|c|c|c|c|c|c|c|}
\hline \multirow{2}{*}{ Desa } & \multirow{2}{*}{$\begin{array}{l}\text { Jlh } \\
\text { Res }\end{array}$} & \multicolumn{2}{|c|}{$\begin{array}{c}\text { Beras } \\
(\mathrm{kg})\end{array}$} & \multicolumn{2}{|c|}{$\begin{array}{l}\text { Jagung } \\
(\mathrm{kg})\end{array}$} & \multicolumn{2}{|c|}{$\begin{array}{l}\text { Ubi Kayu } \\
(\mathrm{kg})\end{array}$} & \multicolumn{2}{|c|}{$\begin{array}{c}\text { Ubi Jalar } \\
(\mathrm{kg})\end{array}$} & \multicolumn{2}{|c|}{$\begin{array}{c}\text { Kacang Hijau } \\
(\mathrm{kg})\end{array}$} & \multicolumn{2}{|c|}{$\begin{array}{l}\text { Kacang Turis } \\
(\mathrm{kg})\end{array}$} \\
\hline & & Per Tahun & $\begin{array}{l}\text { Per } \\
\text { hari }\end{array}$ & Per Tahun & $\begin{array}{l}\text { Per } \\
\text { hari }\end{array}$ & $\begin{array}{l}\text { Per } \\
\text { Tahun }\end{array}$ & $\begin{array}{l}\text { Per } \\
\text { hari }\end{array}$ & $\begin{array}{l}\text { Per } \\
\text { Tahun }\end{array}$ & $\begin{array}{l}\text { Per } \\
\text { hari }\end{array}$ & $\begin{array}{c}\text { Per } \\
\text { Tahun }\end{array}$ & $\begin{array}{l}\text { Per } \\
\text { hari }\end{array}$ & $\begin{array}{l}\text { Per } \\
\text { Tahun }\end{array}$ & $\begin{array}{l}\text { Per } \\
\text { hari }\end{array}$ \\
\hline Nunbena & 26 & 10,059 & 1.06 & 9,696 & 1.02 & $2,800.8$ & 0.30 & $3,232.8$ & 0.34 & 192 & 0.02 & 432 & 0.05 \\
\hline Noebesi & 35 & 13.413 .75 & 1.05 & 12,528 & 0.98 & $3,844.8$ & 0.30 & 4,104 & 0.32 & 2,160 & 0.17 & 1,776 & 0.14 \\
\hline Leloboko & 23 & 6,632 & 0.79 & 8,112 & 0.96 & $2,260.8$ & 0.27 & $1,951.2$ & 0.23 & 528 & 0.06 & 768 & 0.09 \\
\hline Tunua & 50 & 13,688 & 0.75 & 1,3008 & 0.71 & $4,204.8$ & 0.23 & $5,983.2$ & 0.33 & 1,824 & 0.10 & 432 & 0.02 \\
\hline Ajaobaki & 48 & 13,315 & 0.76 & 12,624 & 0.72 & 3,168 & 0.18 & $6,386.4$ & 0.36 & 2,448 & 0.14 & 480 & 0.03 \\
\hline Nuapin & 53 & 17,024 & 0.88 & 16,320 & 0.84 & $3,787.2$ & 0.20 & $3,952.8$ & 0.20 & 4,320 & 0.22 & 2,400 & 0.12 \\
\hline Nenas & 31 & 8,599 & 0.76 & 8,400 & 0.74 & $3,837.6$ & 0.34 & $2,858.4$ & 0.25 & 1,152 & 0.10 & 2,688 & 0.24 \\
\hline Kuanoel & 37 & 10,399 & 0.77 & 9,744 & 0.72 & 3,528 & 0.26 & 4,176 & 0.31 & 1,584 & 0.12 & 1,248 & 0.09 \\
\hline Fatumnasi & 50 & 16,425 & 0.9 & 15,360 & 0.84 & 4,140 & 0.23 & $4,089.6$ & 0.22 & 288 & 0.02 & 1,248 & 0.07 \\
\hline Jumlah & 353 & 96,141 & 7.72 & 105,792 & 7.53 & 31572 & 2.30 & 36734.4 & 2.58 & 14,496 & 0.95 & 11472 & 0.84 \\
\hline Rerata & 39 & $10,682.33$ & 0.86 & $11,754.66$ & 0.83 & 3,508 & 0.25 & $4,081.6$ & 0.28 & $1,610.66$ & 0.10 & $1,274.66$ & 0.09 \\
\hline
\end{tabular}

jalar, kacang hijau dan kacang turis pada setiap rumah tangga dan dihitung secara langsung di lapangan. Konsumsi berbagai jenis pangan yang dikonsumsi oleh setiap keluarga dapat dilihat pada tabel 1 .

Konsumsi pangan pada 9 desa meliputi 6 jenis bahan makanan pokok meliputi beras, jagung, ubi kayu, ubi jalar, kacang hijau, dan kacang turis. Dari berbagai jenis bahan makanan pokok tersebut hanya beras yang bukan merupakan hasil produksi dari lahan pertanian masyarakat. Untuk memperoleh beras, masyarakat membeli di pasar mingguan yang terdapat di kota kecamatan dan dijadikan stok/persediaan untuk 1 (satu) minggu. Sementara itu jagung, ubi kayu, ubi jalar, kacang hijau, dan kacang turis diproduksi di lahan milik, tetapi jumlah yang dikonsumsi untuk setiap keluarga berbeda tergantung pada jumlah hasil produksinya.

Tabel 1 menjelaskan bahwa konsumsi beras per keluarga per hari di Desa Nunbena, Noebesi, Leloboko, Tunua, Ajaobaki, Nuapin, Nenas, Kuanoel dan Fatumnasi berturut-turut $1,06 \mathrm{~kg}, 1,05 \mathrm{~kg}, 0,79 \mathrm{~kg}, 0,75 \mathrm{~kg}, 0,76 \mathrm{~kg}$, $0,88 \mathrm{~kg}, 0,76 \mathrm{~kg}, 0,77 \mathrm{~kg}$ dan $0,9 \mathrm{~kg}$. Terlihat jelas bahwa konsumsi beras setiap keluarga tertinggi di Desa Nunbena dan terendah di Tunua, tetapi secara keseluruhan konsumsi beras per hari setiap keluarga yang di atas $1 \mathrm{~kg}$ hanya di Desa Nunbena dan Noebesi. Sedangkan konsumsi beras per kapita tertinggi di Desa Fatumnasi dan terendah di Ajaobaki, Nenas, dan Kuanoel. Hal ini dapat dipahami karena beras merupakan bahan makanan impor dari luar desa bahkan berasal dari luar kecamatan desa-desa itu berada (Kecamatan Mollo Utara, Kecamatan Nunbena dan Kecamatan Fatumnasi). Untuk mendapatkan beras, masyarakat di Desa Tunua, Ajaobaki, dan Leloboko membeli di pasar Kapan. Masyarakat Desa Noebesi memperolehnya di pasar mingguan Desa Taneotop. Masyarakat Desa Nunbena memperolehnya dengan membeli beras di pasar mingguan Kecamatan Nunbena. Sedangkan masyarakat Desa Nuapin dan Nenas membeli beras di pasar mingguan Desa Nenas. Begitupun juga dengan masyarakat Desa Fatumnasi dan Kuanoel memperoleh beras dengan membeli di pasar mingguan Kecamatan Fatumnasi.

Kontribusi konsumsi beras per keluarga per hari terhadap konsumsi beras total untuk masing-masing desa adalah 13,73 \%, 13,60\%, 
Fransiskus Xaverius Dako, Ris Hadi Purwanto, Lies Rahayu W.Faida, Sumardi -- Tipologi Pola Konsumsi Pangan Untuk Menjaga Ketahanan Pangan Masyarakat Sekitar Kawasan Hutan Lindung Mutis Timau KPH Kabupaten Timor Tengah Selatan

$10,23 \%, 9,71 \%, 9,84 \%, 11,39 \%, 9,84 \%$, $9,97 \%$ dan $11,65 \%$. Dengan jumlah anggota keluarga untuk setiap desanya rata-rata 5 orang (Nunbena, Noebesi, Ajaobaki, Nuapin, Nenas, Kuanoel) dan 4 orang (Leloboko, Tunua, Fatumnasi) maka, konsumsi beras per kapita masing-masing setiap desa di lokasi penelitian adalah 0,21 kg, 0,21 kg, 0,19 kg, 0,18 kg, $0,15 \mathrm{~kg}, 0,17 \mathrm{~kg}, 0,15 \mathrm{~kg}, 0,15 \mathrm{~kg}$ dan 0,22 kg sedangkan konsumsi beras per kapita per tahunnya adalah $76,65 \mathrm{~kg}, 76,65 \mathrm{~kg}, 69,35 \mathrm{~kg}$, $65,7 \mathrm{~kg}, 54,75 \mathrm{~kg}, 62,05 \mathrm{~kg}, 54,75 \mathrm{~kg}, 54,75$ $\mathrm{kg}$, dan $80,3 \mathrm{~kg}$.

Dengan membandingkan konsumsi beras per kapita secara nasional dan Gunung Kidul DIY maka konsumsi beras per kapita di lokasi penelitian sangat kecil. Konsumsi beras nasional per kapita 104,9 kg/kapita/ tahun (Ariani, 2010b) dan 96,2 kg/tahun (Badan Ketahanan Pangan RI, 2018). Apriani dan Baliwati (2011), menjelaskan bahwa konsumsi beras secara nasional untuk desa 109 $\mathrm{kg} / \mathrm{kapita} / \mathrm{tahun}$ dan kota $95 \mathrm{~kg} / \mathrm{kapita} / \mathrm{tahun}$. Rata-rata konsumsi beras dunia hanya $60 \mathrm{~kg} /$ kapita/tahun, Malaysia dan Thailand masingmasing hanya $80 \mathrm{~kg}$ dan $90 \mathrm{~kg} / \mathrm{kapita} / \mathrm{tahun}$ (Ariani, 2010a) sedangkan konsumsi beras di Kecamatan Semin Gunung Kidul adalah sebesar 548,64 kg/kapita/tahun (Suyastiri YP, 2008).

Selain mengkonsumsi beras, masyarakat yang berada di sekitar kawasan hutan lindung Mutis Timau pun mengkonsumsi jagung, ubi kayu, ubi jalar, kacang hijau, dan kacang turis. Jagung (Zea mays) merupakan tanaman pokok yang ditanam oleh masyarakat di Provinsi Nusa Tenggara Timur dan merupakan salah satu tanaman pangan penghasil karbohidrat yang terpenting di dunia. Jagung merupakan sumber pangan yang selalu tersedia pada kondisi apapun baik pada musim hujan maupun pada musim kemarau. Dengan iklim yang kering (8-9 bulan kering) dan 3-4 bulan basah di lokasi penelitian, tanaman jagung cukup adaptif untuk tumbuh subur di lahan pertanian masyarakat. Sebagai tanaman pokok, tentunya hasil produksi jagung cukup tersedia sebagai sumber bahan makanan pokok bagi masyarakat.

Konsumsi jagung per keluarga per hari di Desa Nunbena, Noebesi, Leloboko, Tunua, Ajaobaki, Nuapin, Nenas, Kuanoel, dan Fatumnasi berturut-turut $1,02 \mathrm{~kg}, 0,98 \mathrm{~kg}, 0,96$ $\mathrm{kg}, 0,71 \mathrm{~kg}, 0,72 \mathrm{~kg}, 0,84 \mathrm{~kg}, 0,74 \mathrm{~kg}, 0,72 \mathrm{~kg}$ dan $0,84 \mathrm{~kg}$. Seperti konsumsi beras, konsumsi jagung terbesar di Desa Noebesi dan terkecil di Tunua. Kontribusi konsumsi jagung per hari terhadap konsumsi jagung total per keluarga untuk masing-masing desa adalah 13,54\%, $13,01 \%, 12,74 \%, 9,42 \%, 9,56 \%, 11,15 \%$, 9,82\%, 9,56\% dan 11,15\%. Konsumsi jagung per kapita per hari tertinggi di Desa Leloboko dan terendah di Kuanoel, Nenas, dan Ajaobaki dengan konsumsi setiap desa adalah $0,20 \mathrm{~kg}$, $0,19 \mathrm{~kg}, 0,24 \mathrm{~kg}, 0,17 \mathrm{~kg}, 0,14 \mathrm{~kg}, 0,16 \mathrm{~kg}, 0,14$ $\mathrm{kg}, 0,14 \mathrm{~kg}$ dan $0,21 \mathrm{~kg}$ sedangkan konsumsi per kapita per tahunnya adalah $73 \mathrm{~kg}, 69,35$ $\mathrm{kg}, 87,6 \mathrm{~kg}, 62,05 \mathrm{~kg}, 51,1 \mathrm{~kg}, 58,4 \mathrm{~kg}, 51,1$ $\mathrm{kg}, 51,1 \mathrm{~kg}$, dan $76,65 \mathrm{~kg}$. Konsumsi jagung per kapita per tahun di lokasi penelitian lebih besar dibandingkan dengan konsumsi jagung di Kabupaten Gunung Kidul dan nasional. Suyastiri YP (2008) menjelaskan bahwa konsumsi jagung di Kecamatan Semin Gunung Kidul 19,11 kg/ kapita/tahun dan Ariani (2010b) menyatakan bahwa konsumsi jagung secara nasional 2,9 $\mathrm{kg} / \mathrm{kapita} / \mathrm{tahun}$. Apriani dan Baliwati (2011) menyebutkan konsumsi jagung secara nasional untuk desa 4,69 kg/kapita/tahun dan kota 1,24 $\mathrm{kg} / \mathrm{kapita} /$ tahun. Konsumsi beras dan jagung per kapita per tahun pada setiap desa dapat di lihat pada gambar 1. 
Gambar 1

Konsumsi Beras Dan Jagung Per Kapita (Kg/Kapita/Tahun)

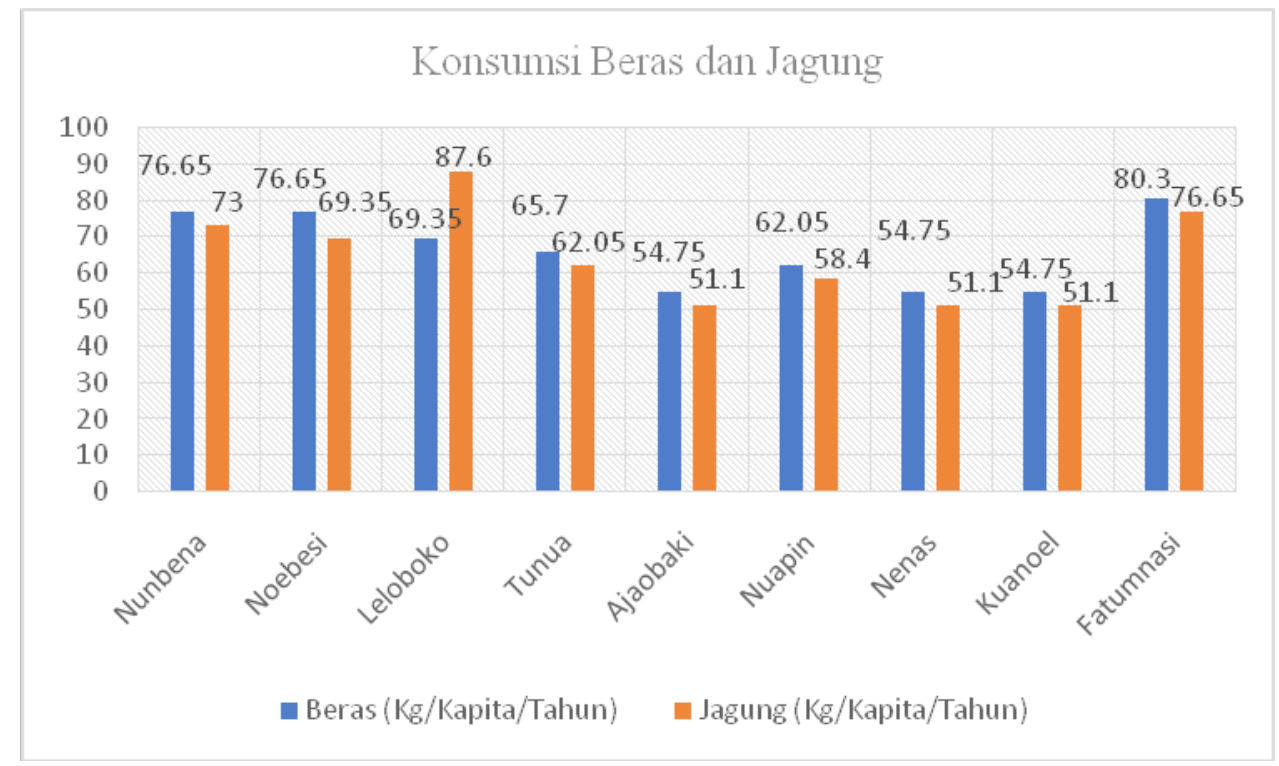

Sumber: Pengolahan Data Primer, 2018

Selain tanaman jagung, tanaman ubi kayu dan ubi jalar merupakan tanaman pokok yang terdapat di lokasi penelitian dengan konsumsi yang bervariasi pada setiap desanya. Kedua jenis tanaman ini tersedia sepanjang tahun, dan saat membutuhkan diambil dari kebun untuk dikonsumsi. Ubi kayu (Manihot esculenta) merupakan tanaman perdu tahunan tropika dan subtropika yang berasal dari suku Euphorbiaceae. Umbi dari tanaman ubi kayu dikenal sebagai makanan pokok penghasil karbohidrat dan daun mentahnya digunakan sebagai sayuran. Konsumsi ubi kayu setiap keluarga terbesar di Desa Nenas dan tertendah di Ajaobaki. Dengan demikian konsumsi ubi kayu setiap keluarga per hari di Desa Nunbena, Noebesi, Leloboko, Tunua, Ajaobaki, Nuapin, Nenas, Kuanoel dan Fatumnasi berturut-turut $0,30 \mathrm{~kg}, 0,30 \mathrm{~kg}, 0,27 \mathrm{~kg}, 0,23 \mathrm{~kg}, 0,18 \mathrm{~kg}$, $0,20 \mathrm{~kg}, 0,34 \mathrm{~kg}, 0,26 \mathrm{~kg}$, dan 0,23 kg.

Kontribusi konsumsi ubi kayu setiap keluarga per hari terhadap konsumsi ubi kayu total untuk masing-masing desa adalah $13,04 \%, 13,04 \%, 11,73 \%, 10 \%, 7,82 \%$,
$8,69 \%, 14,78 \%, 11,30 \%$, dan 10\%. Dilihat dari konsumsi per kapitanya maka konsumsi ubi kayu yang tertinggi adalah di Desa Leloboko dan Nenas serta terendah di Ajaobaki. Konsumsi ubi kayu per kapita per hari masingmasing setiap desa adalah $0,06 \mathrm{~kg}, 0,06 \mathrm{~kg}$, $0,07 \mathrm{~kg}, 0,05 \mathrm{~kg}, 0,03 \mathrm{~kg}, 0,04 \mathrm{~kg}, 0,06 \mathrm{~kg}$, $0,05 \mathrm{~kg}$, dan 0,05 kg sedangkan konsumsi per tahunnya adalah $21,9 \mathrm{~kg}, 21,9 \mathrm{~kg}, 25,5 \mathrm{~kg}$, $18,25 \mathrm{~kg}, 10,95 \mathrm{~kg}, 14,6 \mathrm{~kg}, 21,9 \mathrm{~kg}, 18,25$ dan 18,25 kg. Dengan demikian konsumsi ubi kayu per kapita per tahun di lokasi penelitian lebih kecil dibandingkan dengan konsumsi ubi kayu di Kabupaten Gunung Kidul dan lebih besar dengan konsumsi ubi kayu secara nasional. Suyastiri YP, (2008) menjelaskan bahwa konsumsi ubi kayu di Kecamatan Semin Gunung Kidul 64,89 kg/kapita/tahun sedangkan Ariani (2010b) menyatakan bahwa konsumsi ubi kayu secara nasional 12,9 kg/ kapita/tahun. Menurut Apriani dan Baliwati (2011), konsumsi ubi kayu secara nasional untuk desa 2,51 kg/kapita/tahun dan kota 3,51 $\mathrm{kg} / \mathrm{kapita} /$ tahun. 
Fransiskus Xaverius Dako, Ris Hadi Purwanto, Lies Rahayu W.Faida, Sumardi -- Tipologi Pola Konsumsi Pangan Untuk Menjaga Ketahanan Pangan Masyarakat Sekitar Kawasan Hutan Lindung Mutis Timau KPH Kabupaten Timor Tengah Selatan

Ubi jalar (Ipomea batatas) merupakan salah satu tanaman pokok yang menghasilkan umbi dengan kadar gizi yang tinggi dan tumbuh dengan subur di wilayah penelitian. Konsumsi ubi jalar setiap keluarga pada setiap hari terbesar di Desa Nunbena dan terkecil di Nuapin sedangkan konsumsi per kapitanya terbesar di Desa Tunua dan terkecil di Nuapin. Konsumsi ubi jalar per keluarga per hari di Desa Nunbena, Noebesi, Leloboko, Tunua, Ajaobaki, Nuapin, Nenas, Kuanoel dan Fatumnasi berturut-turut $0,34 \mathrm{~kg}, 0,32 \mathrm{~kg}, 0,23$ $\mathrm{kg}, 0,33 \mathrm{~kg}, 0,36 \mathrm{~kg}, 0,20 \mathrm{~kg}, 0,25 \mathrm{~kg}, 0,31$ $\mathrm{kg}$ dan $0,22 \mathrm{~kg}$. Kontribusi konsumsi ubi jalar setiap keluarga per hari terhadap konsumsi ubi jalar total untuk masing-masing desa adalah $13,17 \%, 12,40 \%, 8,91 \%, 12,79 \%, 13,95 \%$, $7,75 \%, 9,68 \%, 12,01 \%$ dan 8,52\%. Konsumsi ubi jalar per kapita per hari masing-masing setiap desa adalah $0,06 \mathrm{~kg}, 0,06 \mathrm{~kg}, 0,05 \mathrm{~kg}$, $0,08 \mathrm{~kg}, 0,07 \mathrm{~kg}, 0,04 \mathrm{~kg}, 0,05 \mathrm{~kg}, 0,07 \mathrm{~kg}$ dan $0,05 \mathrm{~kg}$ sedangkan konsumsi ubi jalar per kapita per tahun adalah 21,9 kg, 21,9 kg, $18,25 \mathrm{~kg}, 29,2 \mathrm{~kg}, 25,55 \mathrm{~kg}, 14,6 \mathrm{~kg}, 18,25$ $\mathrm{kg}, 25,55 \mathrm{~kg}$ dan 18,25 kg. Dengan demikian dapat disimpulkan bahwa konsumsi ubi jalar di lokasi penelitian jauh lebih besar dari pada konsumsi ubi jalar secara nasional. Ariani (2010b) menyatakan bahwa konsumsi ubi jalar secara nasional 2,8 kg/kapita/tahun. Apriani dan Baliwati (2011) menjelaskan bahwa konsumsi ubi jalar secara nasional untuk desa 0,66 kg/kapita/tahun dan kota 0,209 kg/kapita/ tahun. Konsumsi ubi kayu dan ubi jalar setiap orang per tahun pada setiap desa dapat di lihat pada gambar 2 .

Kacang hijau (Vigna radiata) merupakan jenis tanaman palawija yang termasuk dalam suku polong-polongan dan merupakan sumber bahan pangan berprotein nabati tinggi. Tabel 1 menjelaskan bahwa konsumsi kacang hijau setiap keluarga terbesar di Desa Nuapin dan terkecil di Nunbena dan Fatumnasi. Konsumsi kacang hijau per keluarga per hari di Desa Nunbena, Noebesi, Leloboko, Tunua, Ajaobaki, Nuapin, Nenas, Kuanoel dan Fatumnasi berturutturut $0,02 \mathrm{~kg}, 0,17 \mathrm{~kg}, 0,06 \mathrm{~kg}, 0,10 \mathrm{~kg}, 0,14 \mathrm{~kg}$, $0,22 \mathrm{~kg}, 0,10 \mathrm{~kg}, 0,12 \mathrm{~kg}$ dan $0,02 \mathrm{~kg}$. Kontribusi

Gambar 2

Konsumsi Ubi Kayu dan Ubi Jalar Per Kapita (Kg/Kapita/Tahun)

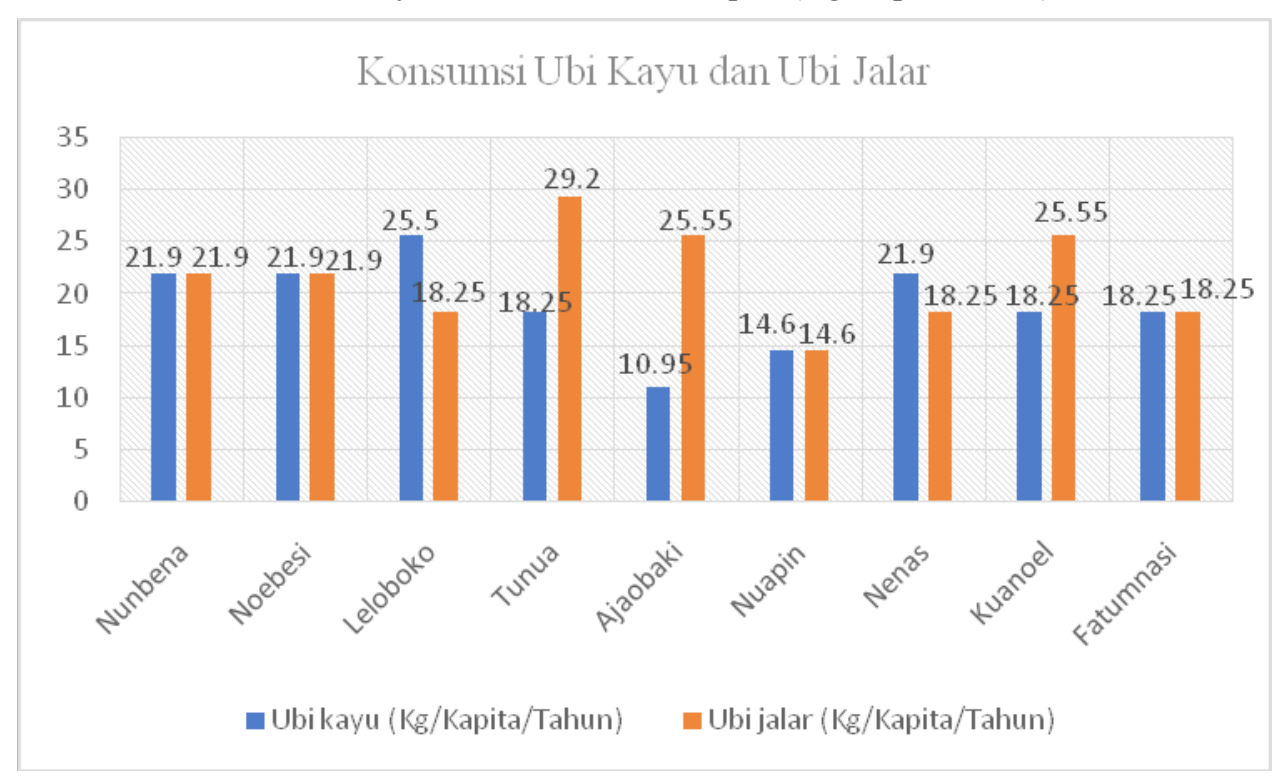

Sumber: Pengolahan Data Primer, 2018 
konsumsi kacang hijau setiap keluarga per hari terhadap konsumsi kacang hijau total masingmasing desa adalah $2,10 \%, 17,89 \%, 6,31 \%$, $10,52 \%, 14,73 \%, 23,15 \%, 10,52 \%, 12,63 \%$, dan 2,10\%. Selain itu konsumsi kacang hijau per kapita di lokasi penelitian tertinggi di Desa Nuapin dan terendah di Nunbena. Konsumsi kacang hijau per kapita per hari masing-masing setiap desa adalah $0,004 \mathrm{~kg}, 0,034 \mathrm{~kg}, 0,01 \mathrm{~kg}$, $0,025 \mathrm{~kg}, 0,028 \mathrm{~kg}, 0,044 \mathrm{~kg}, 0,02 \mathrm{~kg}, 0,024 \mathrm{~kg}$ dan $0,005 \mathrm{~kg}$ sedangkan konsumsi per tahunnya adalah $1,46 \mathrm{~kg}, 12,41 \mathrm{~kg}, 3,65 \mathrm{~kg}, 9,12 \mathrm{~kg}, 10,22$ $\mathrm{kg}, 16,06 \mathrm{~kg}, 7,3 \mathrm{~kg}, 8,76 \mathrm{~kg}$, dan 1,82 kg.

Kacang turis (Cajanus cajan) merupakan jenis tanaman bersifat tahunan dan menjadi sumber pangan alternatif yang cukup adaptif tumbuh di lokasi penelitian. Konsumsi kacang turis per keluarga per hari di Desa Nunbena, Noebesi, Leloboko, Tunua, Ajaobaki, Nuapin, Nenas, Kuanoel dan Fatumnasi berturutturut $0,05 \mathrm{~kg}, 0,14 \mathrm{~kg}, 0,09 \mathrm{~kg}, 0,02 \mathrm{~kg}$, 0,03 kg, 0,12 kg, 0,24 kg, 0,09 kg dan 0,07 $\mathrm{kg}$. Kontribusi konsumsi kacang turis setiap keluarga per hari pada setiap desa terhadap konsumsi kacang turis total masing-masing adalah $5,95 \%, 16,66 \%, 10,71 \%, 2,38 \%$, $3,57 \%, 14,28 \%, 28,57 \%, 10,71 \%$, dan 8,33\%. Konsumsi kacang turis per kapita per hari masing-masing setiap desa adalah 0,001 $\mathrm{kg}, 0,028 \mathrm{~kg}, 0,022 \mathrm{~kg}, 0,005 \mathrm{~kg}, 0,006 \mathrm{~kg}$, $0,024 \mathrm{~kg}, 0,048 \mathrm{~kg}, 0,018 \mathrm{~kg}$ dan $0,017 \mathrm{~kg}$ sedangkan konsumsi per tahunnya adalah $0,365 \mathrm{~kg}, 10,22 \mathrm{~kg}, 8,03 \mathrm{~kg}, 1,825 \mathrm{~kg}, 2,19$ $\mathrm{kg}, 8,76 \mathrm{~kg}, 17,52 \mathrm{~kg}, 6,57 \mathrm{~kg}$ dan $6,20 \mathrm{~kg}$ Dengan demikian hasil konsumsi kacang hijau dan kacang turis di lokasi penelitian lebih kecil dibandingkan dengan konsumsi kacangkacangan di Kota dan Kabupaten Bogor. Waloya, dkk. (2013) menjelaskan bahwa konsumsi kacang-kacangan dan olahannya di Kota dan Kabupaten Bogor 46,69 gram/ kapita/hari untuk pria dan 63,26 gram/kapita/ hari. Konsumsi kacang hijau dan kacang turis per kapita setiap tahun pada setiap desa dapat dilihat pada gambar 3 .

\section{Tipologi Pola Konsumsi Pangan}

Almatsier (2001) mengemukakan bahwa sebagian besar penduduk Indonesia adalah petani yang masih mengandalkan sebagian

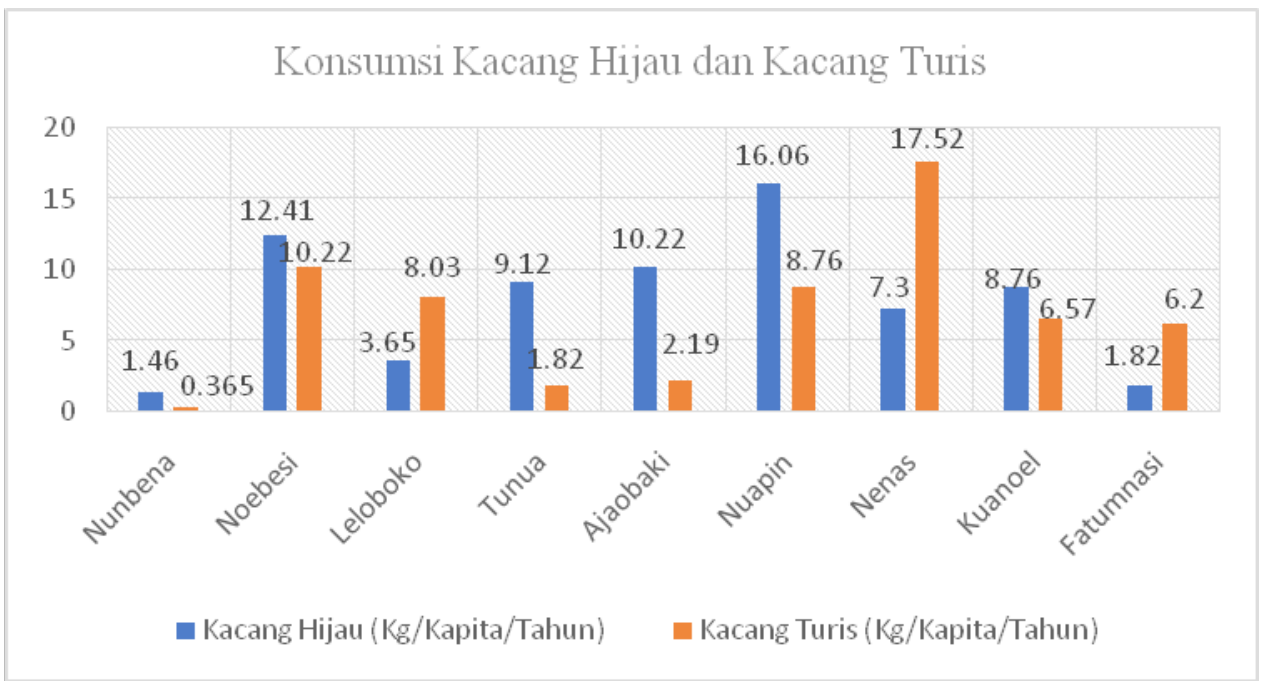

Sumber: Pengolahan Data Primer, 2018 
Fransiskus Xaverius Dako, Ris Hadi Purwanto, Lies Rahayu W.Faida, Sumardi -- Tipologi Pola Konsumsi Pangan Untuk Menjaga Ketahanan Pangan Masyarakat Sekitar Kawasan Hutan Lindung Mutis Timau KPH Kabupaten Timor Tengah Selatan

besar konsumsi makanannya pada makanan pokok. Makanan pokok yang digunakan adalah beras, jagung, umbi-umbian (terutama ubi kayu dan ubi jalar), dan sagu. Dalam kehidupan sehari-hari, penggunaan bahan makanan masyarakat yang berada di dalam dan sekitar kawasan hutan lindung Mutis Timau selalu bergantung pada hasil pertanian yang diperoleh. Secara keseluruhan masyarakat di Pulau Timor bagian barat selalu bergantung pada jenis tanaman yang adaptif di lahan kering yaitu tanaman jagung, ubi kayu, ubi jalar, kacang hijau, dan kacang turis serta jenis tanaman yang lain. Tanaman jagung merupakan salah satu tanaman primadona masyarakat di Provinsi Nusa Tenggara Timur pada umumnya dan Kabupaten Timor Tengah Selatan pada khususnya terlebih di daerah pegunungan Mutis Timau yang tersebar merata di Kecamatan Mollo Utara, Kecamatan Fatumnasi, Kecamatan Nunbena dan beberapa kecamatan lain yang berada di sekitarnya. Selain tanaman jagung, dengan kondisi iklim yang kering beberapa tanaman lain pun tumbuh dan berkembang dengan produksi yang cukup baik seperti ubi kayu, ubi jalar, kacang hijau, kacang merah, kacang tanah, dan kacang turis serta jenis tanaman yang lainnya.

Hasil penelitian menemukan bahwa dalam memenuhi kebutuhan makanan seharihari, masyarakat selalu mengkombinasikan beras dengan berbagai bahan makanan yang diproduksi dari kebun masyarakat seperti jagung, ubi kayu, ubi jalar, kacang hijau, dan kacang turis. Hal ini merupakan suatu tradisi dan budaya pola makan di komunitas Suku Dawan yang diwariskan secara turun temurun oleh para leluhur kepada anggota keluarganya serta sebagai upaya untuk menjaga ketahanan pangan bagi keluarga. Sebelum beras sebagai produk impor masuk dalam tatanan kehidupan masyarakat dalam hal konsumsi pangan, jagung merupakan makanan pokok yang dikonsumsi oleh masyarakat pada setiap harinya. Dalam memasak jagung kebiasaan yang dilakukan oleh keluarga di lokasi penelitian adalah dimasak sendiri maupun dicampur dengan ubi, kacang, dan buah pepaya mentah. Saat ini komoditi jagung dijadikan stok makanan yang disimpan di lopo (rumah tradisional di Suku Dawan) apabila terjadi krisis pangan.

Pengkombinasian beberapa jenis bahan makanan tersebut sebenarnya sebagai upaya untuk menjaga ketahanan pangan keluarga. Penggunaan bahan makanan yang dilakukan oleh masyarakat selalu mengkombinasikan berbagai jenis bahan makanan seperti beras dan jagung (BJ), beras, jagung, dan ubi (BJU), beras, jagung, ubi, dan kacang (BJUK), beras, jagung, dan kacang (BJK) serta beras dan ubi (BU). Penggunaan bahan makanan beras secara terpisah tanpa kombinasi dalam konsumsi pangan oleh rumah tangga di lokasi penelitian terjadi apabila ada anggota keluarga atau tamu yang datang berkunjung, acara resmi, maupun hari raya. Untuk pemenuhan kebutuhan pangan setiap harinya masyarakat selalu mengkombinasikan beras dengan berbagai jenis bahan makanan, tetapi pada hari tertentu setiap minggunya masyarakat mengkonsumsi jagung bose, ubi rebus, kacang rebus, pisang rebus maupun jenis makanan lokal lainnya. Jagung bose, ubi rebus dan kacang rebus merupakan salah satu makanan tradisional yang selalu dikonsumsi oleh masyarakat Suku Dawan di wilayah Kabupaten Timor Tengah Selatan.

Sebagai salah satu makanan tradisional favorit, jagung bose mengalami pergeseran variasi bahan makanan kombinasinya. Jagung bose merupakan salah satu jenis makanan 
tradisional Provinsi Nusa Tenggara Timur khususnya di Pulau Timor bagian barat dengan kombinasi bahan makanan jagung yang dominan, kacang, ubi kayu, ubi jalar dan buah pepaya mentah yang diiris. Di lokasi penelitian masih dijumpai jagung bose dengan berbagai komposisi seperti yang disebutkan, tetapi di daerah perkotaan telah mengalami modifikasi seperti jagung direbus dengan santan dengan campuran kacang merah dan ubi. Jagung bose ini merupakan suatu jenis makanan dengan pola makan yang unik, khas dan beragam serta diwariskan secara turun temurun. Ubi dan kacang yang direbus merupakan salah satu jenis makanan tanpa ada campuran dengan jenis bahan makanan lainnya. Jagung bose, ubi rebus, kacang rebus menjadi santapan rutin yang dilakukan oleh masyarakat bila bahan makanan utama seperti beras tidak tersedia bahkan saat ini pemerintah daerah Kabupaten Timor Tengah Selatan terus menggalakan makanan tradisional tersebut sebagai upaya untuk menjaga ketahanan pangan keluarga. Tipologi konsumsi pangan rumah tangga menurut penggunaan jenis bahan makanan dapat dilihat pada tabel 2.
Tabel 2 menunjukkan bahwa masyarakat yang menggunakan bahan makanan campuran beras dan jagung (BJ) di Desa Nunbena 19,23\%, Tunua 52\%, Ajaobaki 10,41\%, Nuapin 9,43\%, dan Fatumnasi sebanyak 6\%. Masyarakat yang menggunakan bahan makanan BJU di Nunbena 53,84\%, Noebesi 85,71\%, Leloboko 78, 26\%, Tunua 26\%, Ajaobaki 62,5\%, Nuapin 41,50\%, Nenas 48,38\%, Kuanoel $83.37 \%$, dan Fatumnasi 78\%. Masyarakat yang menggunakan bahan makanan BJUK di Desa Nunbena adalah 19,28\%, Noebesi $14,28 \%$, Leloboko $21,73 \%$, Tunua $22 \%$, Ajaobaki 20,83\%, Nuapin 43,39\%, Nenas 48,38\%, Kuanoel 16,21\%, dan Fatumnasi $16 \%$. Masyarakat yang menggunakan bahan makanan BJK di Desa Nunbena 7,69\% dan Nuapin 5,66\%, sedangkan BU hanya terdapat di Desa Ajaobaki 6,25\% dan Nenas 3,22\%.

Kebiasaan makan pada kelompok yang didasarkan status hubungan rumah tangga mempengaruhi distribusi makanan kepada anggota kelompok, yang menyangkut mutu dan jumlah makanan. Distribusi makanan didasarkan pada status hubungan antar anggota rumah tangga dan bukan atas pertimbangan-

Tabel 2

Tipologi Konsumsi Pangan Menurut Penggunaan Jenis Bahan Makanan Berdasarkan Rumah Tangga

\begin{tabular}{|c|c|c|c|c|c|c|c|}
\hline \multirow{3}{*}{ No } & \multirow{3}{*}{ Desa } & \multirow{2}{*}{\multicolumn{5}{|c|}{$\begin{array}{l}\text { Jumlah Rumah Tangga Menurut Penggunaan Jenis Bahan } \\
\text { Makanan }\end{array}$}} & \multirow{3}{*}{ Jumlah } \\
\hline & & & & & & & \\
\hline & & BJ & BJU & BJUK & BJK & $\mathrm{BU}$ & \\
\hline 1 & Nunbena & 5 & 14 & 5 & 2 & 0 & 26 \\
\hline 2 & Noebesi & 0 & 30 & 5 & 0 & 0 & 35 \\
\hline 3 & Leloboko & 0 & 18 & 5 & 0 & 0 & 23 \\
\hline 4 & Tunua & 26 & 13 & 11 & 0 & 0 & 50 \\
\hline 5 & Ajaobaki & 5 & 30 & 10 & 0 & 3 & 48 \\
\hline 6 & Nuapin & 5 & 22 & 23 & 3 & 0 & 53 \\
\hline 7 & Nenas & 0 & 15 & 15 & 0 & 1 & 31 \\
\hline 8 & Kuanoel & 0 & 31 & 6 & 0 & 0 & 37 \\
\hline 9 & Fatumnasi & 3 & 39 & 8 & 0 & 0 & 50 \\
\hline & Jumlah & 44 & 212 & 88 & 5 & 4 & 353 \\
\hline & Persentase (\%) & 12,46 & 60,05 & 24,92 & 1,41 & 1,13 & 100 \\
\hline
\end{tabular}

Sumber: Pengolahan Data Primer, 2018 
Fransiskus Xaverius Dako, Ris Hadi Purwanto, Lies Rahayu W.Faida, Sumardi -- Tipologi Pola Konsumsi Pangan Untuk Menjaga Ketahanan Pangan Masyarakat Sekitar Kawasan Hutan Lindung Mutis Timau KPH Kabupaten Timor Tengah Selatan

pertimbangan kebutuhan gizi (Khumaidi, 1994). Pendapat ini sebenarnya sama dengan kebiasaan makan yang terdapat di 9 desa lokasi penelitian. Makanan yang dikonsumsi hampir sama setiap keluarga dilihat dari entitas jenisnya tetapi berbeda pada ukuran jumlah ketika dimasak, hal ini diperkuat dengan faktor sosial budaya masyarakat yang sama yang berasal dari Suku Dawan.

Dengan kesamaan budaya tersebut sangat mempengaruhi pola dan kebiasaan makan pada setiap keluarga. Makanan yang dimakan oleh satu kelompok masyarakat berbeda dengan makanan yang biasa dimakan oleh kelompok masyarakat yang lain. Penggunaan jenis bahan makanan yang dikonsumsi oleh masyarakat sangat bervariasi pada setiap desa, tetapi pada umumnya masyarakat cenderung mengkombinasikan dengan berbagai bahan makanan tersebut. Seperti pada Tabel 2, bahwa konsumsi rumah tangga yang menggunakan BJ terdapat di Desa Nunbena, Tunua, Ajaobaki, Nuapin dan Fatumnasi. Kombinasi BJU dan BJUK menyebar secara merata di semua desa dengan jumlah rumah tangga yang bervariasi pada setiap desanya. Rumah tangga yang menggunakan konsumsi BJK terdapat di Desa Nunbena dan Nuapin, sedangkan kombinasi BU terdapat di Desa Ajaobaki dan Nenas.

Secara keseluruhan rumah tangga pada lokasi penelitian yang mengkonsumsi BJ 12,46\%, BJU 60,05\%, BJUK 24,92\%, BJK $1,41 \%$ dan BU 1,13\%. Artinya masyarakat yang terdapat di lokasi penelitian lebih dominan menggunakan bahan makanan campuran BJU dibandingkan dengan campuran bahan pangan lainnya. Hal ini disebabkan ketersediaan bahan makanan bukan impor khususnya jagung dan umbi-umbian (ubi kayu dan ubi jalar) banyak terdapat di setiap desa. Dalam kehidupan sehari-hari untuk menjaga ketahanan pangan keluarga, masyarakat selalu mencampur berbagai jenis bahan makanan untuk dimasak secara bersamaan apabila tersedia secara bersamaan. Bila tidak ada beras maka masyarakat mengkonsumsi jagung bose, ubi, dan kacang yang telah direbus.

Jagung bose yang dimaksudkan dalam penjelasan ini adalah jagung kering yang dipipil dan selanjutnya direbus bersamaan dengan berbagai jenis makanan yang lain seperti ubi dan kacang. Tetapi secara keseluruhan tingkat ketergantungan terhadap beras pada setiap desa cukup tinggi. Hal ini diperkuat oleh pendapat Rachman dan Ariani (2008) yang menyatakan bahwa ketergantungan konsumsi pangan masyarakat terhadap pangan sumber karbohidrat, khususnya beras masih sangat tinggi (lebih dari 60\%), sementara di sisi lain peran umbi-umbian, pangan hewani, sayuran dan buah serta kacang-kacangan masih sangat rendah.

Hal yang menarik di lokasi penelitian adalah masyarakat telah melakukan diversifikasi pangan untuk menjaga ketahanan pangan masyarakat melalui pemanfaatan beberapa jenis bahan makanan walaupun dalam ukuran konsumsi per kapitanya masih kecil untuk setiap hari. Pola konsumsi pangan demikian menunjukkan bahwa masyarakat telah mempunyai kesadaran untuk memanfaatkan pangan lokal setempat sebagai suatu strategi untuk menjaga ketahanan pangan masyarakat apabila menghadapi kerawanan pangan. Pola konsumsi pangan ini juga, sudah dilakukan oleh masyarakat secara turun temurun di Suku Dawan yang diwariskan sampai dengan saat ini. Ketahanan pangan pada suatu komunitas/ keluarga sangat dipengaruhi oleh ketersediaan bahan makanan yang dimiliki oleh keluarga di masyarakat. Tetapi kesadaran itu telah terpatri dalam diri masyarakat untuk memanfaatkan 
makanan selain beras dan membutuhkan peran pemberdayaan dari instansi terkait. Suparlan (1993) menyatakan, makanan yang dimakan oleh anggota satu kelompok masyarakat tidak banyak berbeda dan Sediaoetama (1999) menjelaskan bahwa pola makan merupakan konsep budaya yang bertalian dengan makanan dan dipengaruhi oleh unsur sosial budaya yang berlaku dalam kelompok masyarakat seperti nilai sosial, norma sosial, dan norma budaya bertalian dengan makanan (makanan apa yang dianggap baik dan tidak baik).

\section{SIMPULAN}

Berdasar uraian di atas dapat ditarik simpulan sebagai berikut:

Pertama, penggunaan jenis bahan makanan yang dikonsumsi oleh masyarakat pada suatu tempat tergantung pada ketersediaan bahan makanan. Bahan makanan yang dikonsumsi oleh masyarakat pada setiap keluarga di lokasi penelitian terdiri atas beras, jagung, ubi kayu, ubi jalar, kacang hijau, dan kacang turis serta bahan makanan lainnya.

Kedua, konsumsi berbagai jenis bahan makanan setiap keluarga per hari bervariasi pada setiap desa dengan konsumsi rata-rata untuk beras $0,86 \mathrm{~kg}$, jagung $0,83 \mathrm{~kg}$, ubi kayu $0,25 \mathrm{~kg}$, ubi jalar $0,28 \mathrm{~kg}$, kacang hijau $0,10 \mathrm{~kg}$ dan kacang turis $0,09 \mathrm{~kg}$. Sedangkan konsumsi rata-rata per kapita per hari untuk beras 0,18 $\mathrm{kg}$, jagung $0,17 \mathrm{~kg}$, ubi kayu $0,05 \mathrm{~kg}$, ubi jalar $0,06 \mathrm{~kg}$, kacang hijau $0,02 \mathrm{~kg}$ dan kacang turis $0,01 \mathrm{~kg}$. Jumlah rumah tangga yang mengkonsumsi jenis bahan makanan yang dikombinasikan setiap kali masak meliputi BJ 12,46\%, BJU 60,05\%, BJUK 24,92\%, BJK $1,41 \%$, dan BU 1,13\%.

Ketiga, kebiasaan makan dan pola kombinasi bahan makanan sangat dipengaruhi oleh lingkungan, budaya dan ketersediaan bahan makanan. Sebagai upaya untuk menjaga ketahanan pangan masyarakat dan menghindari kerawanan pangan yang dihadapi, Pemerintah Kabupaten Timor Tengah Selatan saat ini mempromosikan makanan lokal tradisional sebagai makanan pokok untuk dikonsumsi di lingkungan keluarga maupun pada acaraacara resmi.

\section{DAFTAR PUSTAKA}

Almatsier, S.2001. Prinsip Dasar Ilmu Gizi, Penerbit Gramedia Pustaka Utama Jakarta.

Apriani, S, Y.F.Baliwati.2011. "Faktor-Faktor yang Berpengaruh Terhadap Konsumsi Pangan Sumber Karbohidrat di Perdesaan dan Perkotaan”. Gizi dan Pangan, 6(3), pp.200-207.

Ariani, M.2010a. "Analisis konsumsi Pangan Tingkat Masyarakat Mendukung Pencapaian Diversifikasi Pangan”. Gizi Indonesia, 33(1), pp.20-28. , 2010b. "Diversifikasi Konsumsi Pangan Pokok Mendukung Swasembada Beras". Prosiding Pekan Serealia Nasional, pp.978-979.

Awang, S.A.2006. Sosilogi Pengetahuan Deforestasi. Konstruksi Sosial dan Perlawanan, Yogyakarta: Penerbit Debut Press.

Badan Ketahanan Pangan RI. 2018. Rencana Strategis Badan Ketahanan Pangan 2015 2019.

Baliwati, Y.I, Roosita, K.2002. Sistem Pangan dan Gizi dalam Pengantar Pangan dan Gizi, Penebar Swadaya Masyarakat.

Blas, A., Garrido, A. \& Willaarts, B.2018. "Food Consumption And Waste In Spanish Households : Water Implications Within And Beyond National Borders". Ecological Indicators, 89(February), pp.290-300. 
Fransiskus Xaverius Dako, Ris Hadi Purwanto, Lies Rahayu W.Faida, Sumardi -- Tipologi Pola Konsumsi Pangan Untuk Menjaga Ketahanan Pangan Masyarakat Sekitar Kawasan Hutan Lindung Mutis Timau KPH Kabupaten Timor Tengah Selatan

Available at: https://doi.org/10.1016/j. ecolind.2018.01.057.

Dako, F. X., Purwanto, R. H., Faida, L. R.,Sumardi. (2018). "Firewood and Carpentry Wood Contribution to The Communities of Mutis Timau Protected Forest, Timor Island". Jurnal Manajemen Hutan Tropika, 24 (December), pp. 166174. doi: 10.7226/jtfm.24.3.166.

Dwiprabowo, H., Effendi, R. \& Hakim, I. 2011. "Kontribusi Kawasan Hutan Dalam Menunjang Ketahanan Pangan: Studi Kasus Propinsi Jawa Barat (Contribution of Forest Area in Supporting Food Security : Case Study of West Java Province)". Jurnal Analisis Kebijakan Kehutanan, 8 Nomor 1,(1), pp.47-61.

Galli, A., Katsunori Iha., Martin Halle, Hamid El Bilali, Nicole Grunewald, Derek Eaton, Roberto Capone, Philipp Debs, Francesco Bottalico. 2017. "Science of the Total Environment Mediterranean countries, Food Consumption And Sourcing Patterns : An Ecological Footprint viewpoint". Science of the Total Environment, The, 578, pp.383-391. Available at: http://dx.doi. org/10.1016/j.scitotenv.2016.10.191.

Garnett, T.,M. C. Appleby, A. Balmford, I. J. Bateman, T. G. Benton, P. Bloomer, B. Burlingame, M. Dawkins, L. Dolan, D. Fraser, M. Herrero, I. Hoffmann, P. Smith, P. K. Thornton, C. Toulmin, S. J. Vermeulen, H. C. J. Godfray. 2013. "Sustainable Intensifi cation in Agriculture : Premises and Policies". Science, 341(Juli), pp.4-5.

Janti, G.I., Martono, E. \& Subeno,.2016. "Perlindungan Lahan Pertanian Pangan Berkelanjutan Guna Memperkokoh Ketahanan Pangan Wilayah (Studi di Kabupaten Bantul, Daerah Istimewa
Yogyakarta)". Jurnal Ketahanan Nasional, 22(1), pp.1-21.

Khumaidi. 1994. Gizi Masyarakat, Jakarta: Penerbit BPK Gunung Mulia Jakarta.

Margareta, D. \& Purwidiani, N. 2014. "Kajian Tentang Pola Konsumsi Makanan Utama Masyarakat Desa". e-Journal Boga, 3, pp.86-95.

Mayrowani, H. \& Ashari. 2011. "Pengembangan Agroforestry Untuk Mendukung Ketahanan Pangan Dan Pemberdayaan Petani Sekitar Hutan (Agroforestry Development to Support Food Security and Farmers 'Empowerment Nearby the Forests)". Forum Penelitian Agro Ekonomi, Volume 29, pp.83-98.

Notarnicola, B., Giuseppe Tassielli, Pietro Alexander Renzulli, Valentina Castellani, S. Sala. 2017. "Environmental Impacts of Food Consumption in Europe". Journal of Cleaner Production, 140, pp.753-765. Available at: $h t t p: / / d x . d o i . o r g / 10.1016 / j$. jclepro.2016.06.080.

Paudel, J. 2018. "Community-Managed Forests, Household Fuelwood Use and Food". Ecological Economics, 147 (August 2017), pp.62-73. Available at: https://doi. org/10.1016/j.ecolecon.2018.01.003.

Purwaningsih, Y. 2008. "Ketahanan Pangan: Situasi, Permasalahan, Kebijakan, Dan Pemberdayaan Masyarakat". Jurnal Ekonomi Pembangunan, 9(1), pp.1-27.

Rachman, Handewi P S. \& Ariani, M. 2008. "Penganekaragaman Konsumsi Pangan di Indonesia: Permasalahan dan Implikasi Untuk Kebijakan Program”. Jurnal Analisis Kebijakan Pertanian, 6(2), pp.140-154.

Sa'diyah, L. 2015. "Kontribusi Joglo Tani Di Mandungan Margoluwih Seyegan 
Sleman Yogyakarta Dalam Peningkatan Peran Pemuda Pada Pembangunan Sektor Pertanian Guna Mewujudkan Ketahanan Pangan". Jurnal Ketahanan Nasional, 21(3), pp.156-162.

Sediaoetama, A. 1999. Imu Gizi untuk Mahasiswa dan Profesi Jilid II., Jakarta: Dian Rakyat Jakarta.

Sevilla CG., Tuwu A, Syah A.1993. Pengantar Metode Penelitian. Jakarta. Universitas Indonesia Press

Simon, H.2004. Aspek Sosio-Teknis Pengelolaan Hutan Jati di Jawa, Yogyakarta: Penerbit Pustaka Pelajar.

Suparlan, P. 1993. Manusia, Kebudayaan, dan Lingkungannya, Jakarta: Raja Grafindo Persada. Jakarta.

Suyastiri YP, N. 2008. "Difersifikasi Konsumsi Pangan Pokok Berbasis Potensi Lokal Dalam Mewujudkan Ketahanan Pangan Rumah Tangga Pedesaan di Kecamatan Semin Kabupaten Gunung Kidul”. Jurnal
Ekonomi Pembangunan, 13 Nomor 1(April), pp.51-60.

Tilman, D. David Tilman,Joseph Fargione,Brian Wolff,Carla D'Antonio, Andrew Dobson, Robert Howarth,David Schindler, William H. Schlesinger, Daniel Simberloff, Deborah Swackhamer. 2001. "Forecasting Agriculturally Driven Global Environmental Change". Science, 292(April), pp.8-10.

Waloya, Tunggul, Rimbawan, Nuri Andarwulan. 2013. "Hubungan Antara Konsumsi Pangan Dan Aktivitas Fisik Dengan Kadar Kolesterol Darah Pria Dan Wanita Dewasa Di Bogor".Gizi dan Pangan, 8(1), pp.9-16.

Wibowo, C.S. 2018. "Dampak Pengalihan Fungsi Lahan Sawah Pada Produksi Padi Sampai Tahun 2018 dan Implikasinya Terhadap Ketahanan Pangan Wilayah ( Studi Di Kecamatan Jaten Kabupaten Karanganyar Propinsi Jawa Tengah )". Jurnal Ketahanan Nasional, 21, pp.107-117. 